\title{
Pelatihan Mendesain Pembelajaran Daring Menarik Selama Pandemi Covid-19 dengan Teknologi Pembelajaran Sederhana
}

\author{
Adaninggar Septi Subekti ${ }^{1}$, Lemmuela Alvita Kurniawati ${ }^{2}$ \\ 1,2Universitas Kristen Duta Wacana (UKDW), Yogyakarta \\ Email: adaninggar@staff.ukdw.ac.id1; pipitkh@staff.ukdw.ac.id²
}

\begin{abstract}
This community service was carried out to provide assistance to the situation experienced by English high school teachers in the sudden change of the learning modes due to the Covid-19 pandemic. It was conducted in the form of an online seminar on how to design interesting online learning by using simple instructional technology and how to combine asynchronous and synchronous learning modes. The 150-minuteonline seminar was held on the Zoom platform and YouTube livestreaming. The session was divided into three main parts, namely 1) introduction of the $5 E$ framework for online learning, 2) examples of material design using simple instructional technology, and 3) examples of simple instructional technology. In general, it can be concluded that this community service not only provided an introduction and understanding of online learning design with simple instructional technology, but also enhanced the participants' pedagogical knowledge of online learning design.
\end{abstract}

Keywords: Community service, online seminar, instructional technology, 5E Framework, Covid-19 pandemic.

\begin{abstract}
Abstrak
Kegiatan pengabdian kepada masyarakat (PKM) ini dilaksanakan untuk memberikan pendampingan terhadap situasi yang dialami para guru Bahasa Inggris Sekolah Menengah Atas (SMA) terhadap perubahan mode pembelajaran yang begitu mendadak karena terjadinya pandemi Covid-19. Kegiatan yang dilaksanakan dalam bentuk seminar daring ini memberikan pemaparan mengenai cara mendesain pembelajaran daring yang menarik dengan menggunakan teknologi sederhana dan kombinasi pembelajaran sinkronus asinkronus. Seminar daring dilaksanakan dengan menggunakan platform Zoom dan livestreaming di YouTube dalam waktu 150 menit. Paparan materi mengenai mendesain pembelajaran daring yang menarik dengan teknologi pembelajaran sederhana ini dibagi menjadi tiga bagian utama, yaitu 1) pengenalan framework $5 E$ untuk pembelajaran daring, 2) contoh desain materi dengan menggunaan teknologi pembelajaran sederhana, dan 3) contoh teknologi pembelajaran sederhana. Secara umum dapat disimpulkan bahwa kegiatan PKM ini memberikan pengenalan dan pemahaman mengenai desain pembelajaran daring dengan teknologi sederhana dan meningkatkan kemampuan pedagogik peserta mengenai desain PJJ.
\end{abstract}

Kata kunci: PKM, seminar daring, teknologi pembelajaran, framework 5E, pandemi Covid-19

\section{PENDAHULUAN}

Pandemi Covid-19 yang pertama kali muncul di kota Wuhan, Tiongkok, menjelang akhir tahun 2019 telah membawa perubahan besar terhadap hidup manusia di dunia sekarang ini. Sampai awal Agustus 2020, virus ini tercatat telah menginfeksi 18 juta lebih penduduk dunia dengan angka kematian melebihi 680 ribu. Sekolah dan universitas di dunia tidak lagi melakukan pembelajaran tatap muka dan mulai memberlakukan pembelajaran jarak jauh (PJJ) dan daring untuk mencegah terjadinya penularan virus sejak Maret 2020. Diperkirakan sekitar satu milyar siswa di seluruh dunia harus melakukan PJJ untuk tetap belajar karena ditutupnya sekolah dari kegiatan pembelajaran tatap muka di tengah pandemic (Mondol \& Mohiuddin, 2020). Meskipun PJJ dimungkinkan tetap berjalan dengan adanya teknologi, terutama teknologi internet, perubahan mode pembelajaran dari mode luring ke daring tidak hanya memberikan tantangan kepada para siswa tapi juga para guru. Apalagi perubahan terjadi begitu mendadak dan tanpa persiapan dikarenakan pandemi ini. Khusus pada konteks pembelajaran di Indonesia, PJJ juga memberikan tantangan tersendiri. Kemampuan siswa Indonesia yang beragam dari segi akses ke 
teknologi dan kepemilikan fasilitas pendukung PJJ seperti laptop dan ponsel pintar menjadi salah satu aspek yang harus dipahami oleh para guru selama PJJ selain juga kebutuhan untuk memberikan pembelajaran yang berjalan relatif baik untuk para siswa (Megawanti et al., 2020; Subekti, dalam review).

Atas dasar kebutuhan inilah, kami (penulis) melakukan kerjasama dengan Musyawarah Guru-Guru Mata Pelajaran (MGMP) Bahasa Inggris Sekolah Menengah Atas (SMA) Propinsi Daerah Istimewa Yogyakarta (DIY) untuk mengadakan seminar daring bertema penggunaan teknologi pembelajaran sederhana untuk mendukung pelaksanaan PJJ terutama di level SMA. Kegiatan ini merupakan perwujudan dari salah satu Tridharma Perguruan Tinggi, yaitu pengabdian kepada masyarakat, utamanya sumbangsih dosen dalam mendukung para guru SMA untuk semakin berdaya dalam mendidik para siswa (contoh lain: Awal et al., 2019; Subekti \& Susyetina, 2019). Selain itu, pelatihan ini juga didasari secara langsung oleh nilai dasar Universitas Kristen Duta Wacana (UKDW) yang sering disebut "nilai dasar Kedutawacanaan" yang keempat yaitu "Melayani Dunia" dan secara tidak langsung oleh nilai-nilai dasar yang pertama sampai dengan ketiga, yaitu: Menanti Allah, Melangkah dalam Integritas, dan Melakukan yang Terbaik (Universitas Kristen Duta Wacana, 2017). Diharapkan dengan seminar penggunaan teknologi pembelajaran sederhana ini, para guru SMA yang menjadi peserta kemudian dapat mengimplementasikan ilmu yang didapat untuk memfasilitasi para siswa untuk tetap belajar secara optimal di tengah situasi yang tidak mudah selama pandemi ini.

\section{METODE}

Pertemuan antara penulis (pelaksana PKM) dan pihak MGMP Bahasa Inggris DIY menyepakati adanya seminar daring dengan para guru Bahasa Inggris SMA sebagai target peserta utama. Pembicara seminar berasal dari dosen Program Studi Pendidikan Bahasa Inggris (Prodi PBI) Universitas Kristen Duta Wacana (UKDW) dan dari pihak MGMP Bahasa Inggris DIY karena dirasa perlu untuk juga memberdayakan guru anggota MGMP dalam berbagi pengalaman mengajar selama PJJ kepada para peserta sesama guru. Selanjutnya karena sifat seminar yang dilaksanakan secara daring dan harapan bahwa seminar ini bisa memberikan sebesar mungkin manfaat bagi para praktisi kependidikan, dimungkinkan adanya peserta yang bukan guru Bahasa Inggris SMA, misalnya dari kalangan dosen Bahasa Inggris, guru Sekolah Menengah Pertama (SMP), praktisi pendidikan, maupun mahasiswa Prodi PBI dari dalam maupun luar UKDW. Publikasi dan pendaftaran kegiatan dilakukan seminggu sebelum kegiatan berlangsung dalam bentuk poster.

PKM ini dilaksanaan pada hari Sabtu, 4 Juli 2020 dari pukul 09.30 sampai dengan pukul 12.00 melalui platform Zoom dengan live streaming di Youtube. Sesi dimulai dengan pemaparan materi kemudian dilanjutkan dengan sesi tanya jawab. Pemaparan materi sesi pertama dilakukan oleh salah satu perwakilan MGMP Bahasa Inggris SMA mengenai penggunaan Microsoft Kaizala sementara kami (penulis) melakukan pemaparan materi pada sesi kedua dengan tema "Mendesain Pembelajaran Daring yang Sederhana dan Menarik dengan Prinsip 5E." Sebelum sesi berakhir, panitia seminar daring membagikan tautan formulir evaluasi kepada peserta melalui pesan di kotak percakapan. Formulir evaluasi tersebut berisi serangkaian pertanyaan mengenai topik, penyampaian materi, dan saran untuk seminar daring yang akan dilaksanakan di waktu mendatang.

\section{HASIL DAN PEMBAHASAN}

Pemaparan materi dengan tema "Mendesain Pembelajaran Daring yang Sederhana dan Menarik dengan Prinsip 5E" dibagi menjadi tiga bagian utama, yaitu: pengenalan framework 5E dalam mendesain pembelajaran daring, contoh desain materi menggunakan teknologi pembelajaran sederhana, dan contoh-contoh teknologi pembelajaran sederhana yang dapat digunakan para peserta. 
Peserta dikenalkan Framework 5E yang terdiri dari: Engage (Menarik perhatian siswa), Explore (Eksplorasi), Explain (Penjelasan), Elaborate (Elaborasi), dan Evaluate (Evaluasi) (Carrejo \& Reinhartz, 2014). Dikemukakan beberapa alasan penggunaan Framework 5E untuk mendesain pembelajaran. 5E memungkinkan inquiry-based teaching di mana siswa berperan aktif dalam mencari dan menemukan informasi sendiri (Jeter et al., 2019). Dengan demikian, 5E dapat memfasilitasi pembelajaran aktif di mana guru berperan sebagai fasilitator dengan siswa sebagai pihak yang secara aktif berperan dalam proses pembelajaran mereka (Jeter et al., 2019).

Berikut tahap-tahap 5E yang dipaparkan kepada peserta beserta contoh konkret pelaksanaan di kelas. Pada tahap Engage, dijelaskan bahwa guru memulai pembelajaran dengan memancing perhatian siswanya melalui hal-hal yang sudah mereka ketahui dan hal-hal yang ingin mereka ketahui (Duran et al., 2011). Misalnya untuk menyampaikan materi "Describing Places" atau mendeskripsikan tempat, pada tahap ini perhatian siswa terhadap topik dapat dipancing dengan menggunakan pertanyaan seperti objek wisata apa saja yang mereka ketahui. Kemudian mereka diminta untuk memilih salah satu objek wisata dan mulai memikirkan hal-hal apa saja yang mereka ingin ketahui lebih dalam mengenai objek wisata tersebut. Teknologi pembelajaran yang dapat digunakan pada tahap ini misalnya Padlet, Mentimeter, maupun WhatsApp chat. Pada tahap berikutnya, yaitu Explore, siswa mengeksplorasi topik yang sedang dibahas melalui contohcontoh konkret (Duran et al., 2011). Misalnya, siswa diminta melakukan penelusuran daring secara lebih detail tentang objek wisata yang telah mereka pilih, aktivitas yang sering dilakukan di sana, fasilitas, sejarah, karakteristik, dan bagaimana pengujung dapat mencapai destinasi tersebut. Kegiatan eksplorasi ini juga dimungkinkan dilakukan secara luring, misalnya siswa bertanya tentang sejarah tempat tersebut kepada orang tua dan pihak lain. Pada tahap Explain, siswa melaporkan apa saja yang telah mereka pelajari di tahap Explore yang telah dilakukan sebelumnya (Duran et al., 2011). Akivitas ini bisa dilakukan secara synchronous atau pun asynchronous, baik secara lisan melalui video atau pun audio maupun secara tertulis tergantung dari keterampilan/skill yang ingin dicapai. Pada tahap Explain inilah, guru dapat membetulkan kesalahan atau miskonsepsi siswa (Duran et al., 2011), misalnya apabila ada kesalahan tata bahasa/grammar. Selanjutnya, pada tahap Elaborate, siswa merekonstruksi pemahaman mereka dan mengaplikasikan hal yang sudah mereka pelajari dalam konteks (Duran et al., 2011). Sebagai contoh, setelah siswa melaporkan hasil penelusuran daring tentang suatu objek wisata, mereka dapat menuangkan apa yang telah mereka pelajari dalam suatu karya yang relevan. Misalnya, setelah mereka berhasil mengetahui beberapa hal terkait Keraton Yogyakarta, mereka bisa membuat poster atau pamflet promosi wisata, infografik tentang Keraton Yogyakarta. Pembuatan poster atau infografik digital dapat menggunakan aplikasi online Canva. Apabila siswa mengalami kendala terkait akses dan kuota internet, dimungkinkan pembuatan poster/infografik dengan tulisan tangan yang kemudian dipotret dan dikumpulkan melalui WhatsApp chat. Selanjutnya, Evaluate adalah tahapan terakhir dari Framework 5E. Pada tahap ini, guru melakukan evaluasi atas proses dan hasil belajar siswa. Evaluasi yang bersifat sumatif dapat dilakukan dalam bentuk pemberian tes atau kuis, sementara evaluasi yang bersifat formatif dapat dilakukan selama siswa berproses pada tahap-tahap sebelumnya. Dipaparkan juga bahwa pada tahap ini, siswa dapat difasilitasi untuk saling memberikan penilaian terhadap hasil kerja teman mereka. Kami lebih menekankan pada potensi penilaian sebaya secara kualitatif dengan cara memberikan komentar dan umpan balik konstruktif terhadap hasil kerja teman untuk semakin memupuk semangat dan atmosfer kerjasama (cooperative learning) dan mengurangi atmosfer kompetensi antar-siswa (Dar et al., 2014; Gupta et al., 2019).

Setelah mencapai tahap Evaluate, pembelajaran dapat kembali dimulai dengan tahap Engage untuk kompetensi dasar atau capaian pembelajaran berikutnya. Sehingga, dapat dikatakan bahwa 5E adalah proses yang sifatnya siklus/cyclic atau tidak berkesudahan. 5E dapat dilihat pada Gambar 1 (The 5E Instructional Model, 2020). 


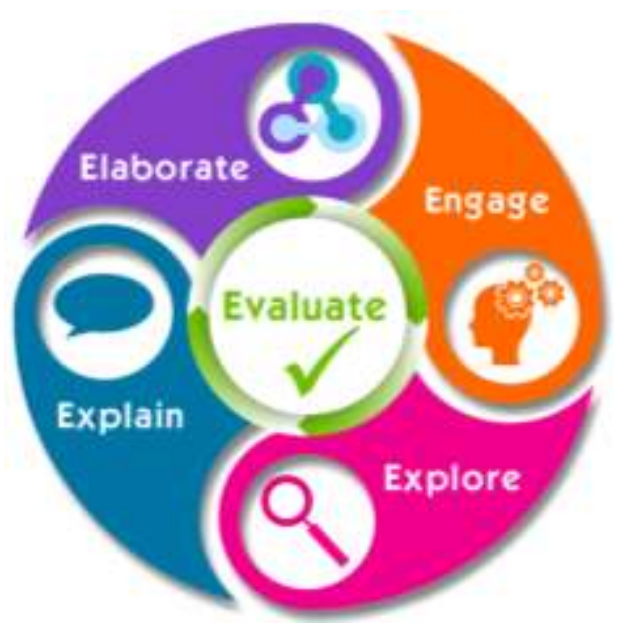

Gambar 1. Framework 5E yang berbentuk siklus

Selain penjelasan tentang 5E, dipaparkan juga beberapa hal mendasar terkait pembelajaran daring kepada para peserta. Pertama terkait synchronous instruction, pembelajaran yang dilakukan secara live/real-time, biasanya melalui teleconference, dan asynchronous instruction, pembelajaran yang dilakukan tidak secara real-time, misalnya tugas diberikan oleh guru untuk diselesaikan dan dikumpulkan siswa dalam durasi satu minggu (Plaisance, 2018). Dijelaskan bahwa pembelajaran daring yang ideal harus mengkombinasikan antara synchronous dan asynchronous instructions (Moorhouse, 2020; Plaisance, 2018). Mode synchronous memungkinkan interaksi guru-murid secara langsung sehingga kesulitan belajar dan pertanyaan siswa terkait materi dapat langsung direspon. Sementara itu mode asynchronous memungkinkan siswa memiliki lebih banyak waktu untuk menyelesaikan tugas (misal dalam seminggu) baik secara individu maupun kelompok dan membutuhkan kuota internet rendah sehingga tidak memberatkan siswa secara ekonomi (Plaisance, 2018). Selain itu para peserta yang sebagian besar adalah para guru tidak perlu merasa khawatir bahwa PJJ menuntut kemampuan literasi teknologi yang sangat tinggi dari para guru. Kami paparkan bahwa yang paling utama yang harus dipikirkan dalam merancang PJJ adalah kompetensi apa yang ingin dicapai bukan teknologi apa yang harus dipakai (Tasks before Apps) (An \& Reigeluth, 2011). Guru baru kemudian memikirkan teknologi pembelajaran apa yang dapat digunakan untuk mencapai kompetensi tersebut dengan berbagai pertimbangan (An \& Reigeluth, 2011) misalnya kelebihan teknologi tersebut, kemampuan gawai yang dimiliki siswa, dan tingkat kemampuan mereka secara ekonomi (misalnya untuk membeli kuota internet).

Pada sesi tanya jawab, beberapa pertanyaan diajukan terkait pemaparan materi. Beberapa pertanyaan yang diajukan di antaranya tentang implementasi penilaian sebaya selama PJJ, porsi synchronous instruction selama PJJ apakah harus ada, dan bagaimana memfasilitasi pembelajaran siswa berkebutuhan khusus dengan kemampuan literasi teknologi yang sangat lemah. Menganggapi pertanyaan tentang penilaian sebaya selama PJJ, dijelaskan bahwa penilaian sebaya baru bisa dilakukan dengan proses pembiasaan yang telah dilakukan sebelumnya dan tidak disarankan untuk dilakukan secara mendadak tanpa membekali para siswa tentang bagaimana melakukan penilaian sebaya dengan baik. Proses pembiasaan misalnya dengan mengenalkan siswa rubrik penilaian dan pentingnya memberikan penilaian yang objektif untuk perkembangan belajar teman mereka. Penilaian yang sifatnya kualitatif misalnya berupa komentar yang konstruktif terhadap hasil kerja teman juga lebih disarankan daripada penilaian sebaya yang berupa penilaian kuantitatif karena dimungkinkan adanya bias dalam penilaian karena hubungan pertemanan (Azarnoosh, 2013; Izati, 2018). Selanjutnya terkait apakah synchronous instruction yang relatif boros kuota internet harus diberi porsi selama PJJ mengingat kemampuan gadget dan ekonomi siswa yang beragam dan cenderung terbatas, kami menjelaskan kepada peserta bahwa idealnya synchronous instruction diberikan porsi meskipun tidak besar. Hal 
ini juga untuk menjaga sense of community para siswa selama belajar di rumah, supaya mereka tidak merasa sendiri dalam proses pembelajaran di rumah, dan menunjukkan bahwa guru selalu hadir untuk memfasilitasi proses belajar mereka (Subekti, dalam review). Sebagai pengganti synchronous instruction, guru bisa mengirimkan rekaman video mereka menjelaskan suatu materi melalui chat platform seperti WhatsApp daripada sekedar memberikan tugas untuk dikumpulkan. Selanjutnya, menanggapi pertanyaan terkait bagaimana memfasilitasi pembelajaran siswa berkebutuhan khusus dengan kemampuan literasi teknologi yang sangat lemah, kami menjelaskan diperlukannya differentiated instruction atau pembelajaran berdeferensiasi di mana kepada siswa tersebut diberlakukan metode, asesmen, dan evaluasi yang dibedakan dari siswasiswa yang lain (Subekti, 2020b, 2020a).

Hampir 200 peserta pengajar Bahasa Inggris dari seluruh Indonesia, terutama anggota MGMP Bahasa Inggris SMA DIY mengikuti seminar daring ini melalui platform Zoom maupun live streaming di Youtube. Situasi seminar daring melalui platform Zoom dan Youtube masing-masing dapat dilihat pada Gambar 2 dan 3.

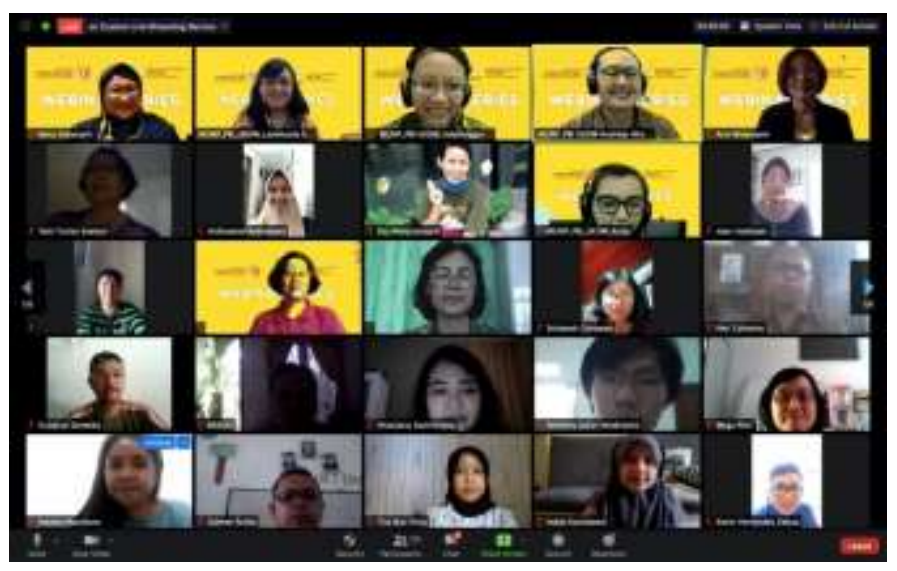

Gambar 2. Situasi seminar daring di Zoom
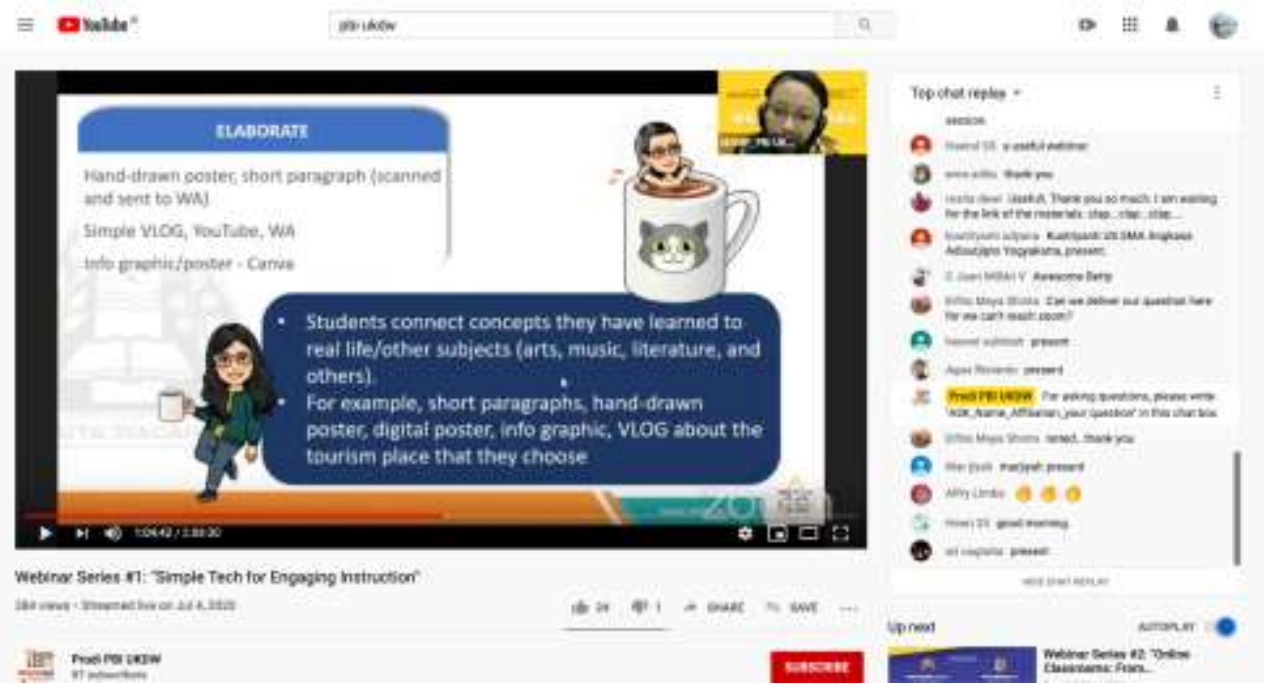

Gambar 3. Situasi seminar daring di Youtube

Dari 167 kuesioner evaluasi pelaksanaan kegiatan yang diisi oleh para peserta, didapatkan data bahwa secara umum materi kegiatan dipandang sesuai dengan kebutuhan para guru selama PJJ. Meskipun terdapat dua peserta yang menyatakan materi yang disampaikan "kurang sesuai", 117 peserta menyatakan "sangat sesuai", 27 peserta menyatakan "sesuai", dan satu peserta menyatakan "cukup sesuai". Hasil selengkapnya ini dapat dilihat pada Gambar 4. 


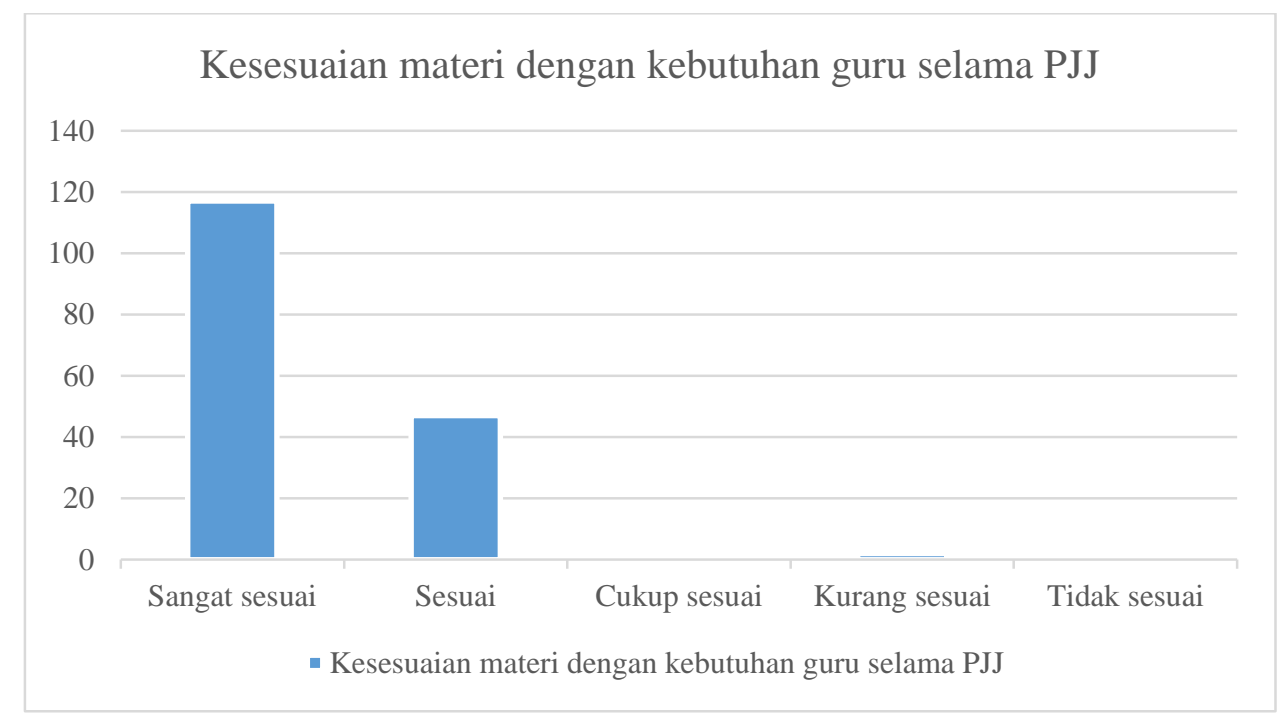

Gambar 4. Hasil kuesioner evaluasi peserta

Kami juga mendapatkan umpan balik secara kualitatif dari peserta. Terkait sejauh mana pelaksanaan kegiatan ini telah berjalan baik, beberapa komentar positif yang kami dapatkan antara lain "Penjelasan pemateri singkat, padat dan mudah dipahami", "The topics are up to date, very useful and give new insight to education" (Topik yang disampaikan terkini, sangat berguna, dan memberikan pandangan baru dalam pendidikan", dan "Saya suka materinya. Menuangkannya dalam PowerPoint pun sangat sederhana dan mudah dipahami. Ketika menjawab pertanyaan dari peserta, pembicara juga langsung straight to the point [langsung pada pokok persoalan], memberi contoh yang mendukung jawaban mereka berdasarkan pengalaman." Namun demikian, kami juga mendapatkan beberapa umpan balik konstruktif tentang aspek yang masih dapat ditingkatkan, misalnya untuk memperbanyak materi tentang aplikasi PJJ rendah kuota internet dan implementasi teori dengan contoh-contoh konkret yang lebih banyak. Dari sini, kami menyadari keinginan yang besar dari para guru Bahasa Inggris, terutama guru-guru Bahasa Inggris SMA, untuk dapat menfasilitasi PJJ para siswa selama pandemi ini dengan seoptimal mungkin meskipun dengan segala keterbatasan yang ada. Semangat ini patut diapresiasi dan terus didukung. Di sinilah dosen Bahasa Inggris dapat mengambil peran untuk membantu para guru, memberikan pemahaman, informasi baru, dan bahkan memupuk semangat mereka bahwa selalu ada jalan dalam setiap kesulitan dan bahwa pandemi ini dapat dijadikan momentum untuk semakin mengasah kemampuan para guru baik secara pedagogik maupun profesional.

\section{KESIMPULAN}

Dari kegiatan PKM dalam bentuk seminar daring ini dapat diambil beberapa kesimpulan. Pertama, dari umpan balik yang didapatkan dari peserta, dapat disimpulkan bahwa topik yang kami bagi dan paparkan sesuai dengan kebutuhan para peserta seminar daring. Peserta seminar daring dapat secara langsung mengaplikasikan framework 5E dalam PJJ mata pelajaran Bahasa Inggris. Contoh-contoh kegiatan dan penggunaan teknologi pembelajaran sederhana yang dijelaskan dalam tiap tahap framework $5 \mathrm{E}$ juga memberi gambaran yang lebih konkret dan detail bagi para peserta dalam merencanakan kegiatan pembelajaran dengan framework 5E. Selain itu, paparan mengenai kombinasi pembelajaran synchronous dan asynchronous memberikan penjelasan kepada para peserta pentingnya mengkombinasikan kedua jenis pembelajaran daring tersebut. Dengan kombinasi pembelajaran synchronous dan asynchronous, interaksi antara gurumurid dalam hal membimbing siswa serta memberi umpan balik dapat terjadi secara real-time dan siswa mendapatkan waktu yang lebih lama dalam mengerjakan tugas-tugas yang diberikan 
guru. Paparan kami yang menggarisbawahi mengenai pentingnya kompetensi dasar yang perlu dicapai juga memberikan penjelasan pada para peserta seminar daring mengenai orientasi proses pembelajaran pada kompetensi dasar dan pemilihan teknologi pembelajaran berdasarkan kompetensi dasar tersebut. Kedua, melalui kegiatan ini, mitra kami yaitu MGMP Bahasa Inggris SMA DIY, secara langsung memfasilitasi kebutuhan dan memberi dukungan pada para guru Bahasa Inggris SMA di DIY dalam melaksanakan PJJ selama pandemi. Menyadari kebutuhan para guru Bahasa Inggris SMA DIY terhadap sesi berbagi pengetahuan, keterampilan, dan praktik baik PJJ selama masa pandemi, MGMP Bahasa Inggris DIY berkolaborasi dengan Prodi PBI UKDW untuk dapat mengupayakan kegiatan yang memberdayakan, memotivasi, dan mengasah pengetahuan serta keterampilan para guru. Selanjutnya, kami sebagai narasumber seminar juga banyak belajar bagaimana menggunakan keilmuan kami dalam memberikan pendampingan, inspirasi, dan semangat pada para guru. Terlebih selama masa pandemi ini, para dosen, dengan keilmuan yang mereka miliki, berperan dalam mengenalkan dan memberikan pemahaman terhadap ilmu dan informasi baru serta mengembangkan kinerja dan profesionalitas guru berkelanjutan. Bentuk kontribusi tersebut, selain merupakan salah satu bagian dari Tridharma Perguruan Tinggi, secara langsung juga merupakan bentuk manifestasi dari nilai-nilai dasar Kedutawacanaan yang kami anut.

\section{DAFTAR PUSTAKA}

An, Y.-J., \& Reigeluth, C. (2011). Creating technology-enhanced, learner-centered classrooms. Journal of Digital Learning in Teacher Education, 28(2), 54-62. https://doi.org/10.1080/21532974.2011.10784681

Awal, R., Wahyuni, S., \& Sari, M. (2019). Pelatihan penggunaan aplikasi Edmodo bagi guru SMP dan SMA Smart Indonesia Pekanbaru. Dinamisia: Jurnal Pengabdian Kepada Masyarakat, 3(1), 69-75. https://doi.org/10.31849/dinamisia.v3i1.2218

Azarnoosh, M. (2013). Peer assessment in an EFL context: Attitudes and friendship bias. Language Testing in Asia, 3(11), 1-10.

Carrejo, D. J., \& Reinhartz, J. (2014). Teachers fostering the co-development of science literacy and language literacy with English language learners. Teacher Development, 18(3), 37-41. https://doi.org/10.1080/13664530.2014.914564

Dar, M. F., Zaki, S., \& Kazmi, H. H. (2014). Peer assessment in EAP writing: An effective strategy for large classes. Journal of Educational Research, 17(1), 50-60.

Duran, E., Duran, L., Haney, J., \& Scheuermann, A. (2011). A learning cycle for all students: Modifying the 5E instructional model to address the needs of all learners. The Science Teacher, March, 56-60.

Gupta, S. D., Abdullah, F. A., \& Xueshuang, Y. (2019). Peer assessment in writing: A critical review of previous study. Journal of Advances in Linguistics, 10, 1478-1487.

Izati, R. A. (2018). The influence of friendship bias toward peer assessment in EFL classroom. RETAIN, 6(2), 52-59.

Jeter, G., Baber, J., Heddy, B., Wilson, S., Williams, L., Atkinson, L., Dean, S., \& Gam, G. (2019). Students at the center: Insights and implications of authentic, 5E instruction in high school English language arts. Frontiers in Education, 4, 1-11. https://doi.org/10.3389/feduc.2019.00091

Megawanti, P., Megawati, E., \& Nurkhafifah, S. (2020). Persepsi peserta didik terhadap PJJ pada masa pandemi Covid-19. Faktor Jurnal Ilmiah Kependidikan, 7(2), 75-82.

Mondol, S., \& Mohiuddin, M. G. (2020). Confronting Covid-19 with a paradigm shift in teaching and learning: A study on online classes. International Journal of Social, Political and Economic Research, 7(2), 231-247.

Moorhouse, B. L. (2020). Adaptations to a face-to-face initial teacher education course 'forced' online due to the COVID-19 pandemic. Journal of Education for Teaching, 00(00), 1-3. https://doi.org/10.1080/02607476.2020.1755205

Plaisance, M. (2018). Online course delivery. Dalam J. I. Liontas (Ed.), The TESOL encyclopedia of 
English language teaching (First https://doi.org/https://doi.org/10.1002/9781118784235.eelt0129

Subekti, A. S. (dalam review). Covid-19-triggered online learning implementation: Pre-service English teachers' beliefs. Metathesis: Journal of English Language Literature and Teaching.

Subekti, A. S. (2020a). Guided translation to channel an autistic learner's potentials in L2 writing: A case study. Jurnal Pendidikan Progresif, 10(2).

Subekti, A. S. (2020b). Self-made vocabulary cards and differentiated assessments to improve an autistic learner's English vocabulary mastery. International Journal of Education, 13(1).

Subekti, A. S., \& Susyetina, A. (2019). Pelatihan mengajar dan menulis laporan hasil belajar dalam Bahasa Inggris untuk guru SMP/SMA Tumbuh Yogyakarta. Jurnal Pengabdian UntukMu NegeRI, 3(2), 89-96.

The 5E instructional model. (2020). Nasa EClips. https://nasaeclips.arc.nasa.gov/teachertoolbox/the5e\#collapseOne

Universitas Kristen Duta Wacana (2017). Nilai-nilai universitas. https://www.ukdw.ac.id/profil/nilai-nilai-ukdw/ 